\title{
Current and future land use and land cover scenarios in the Arroio Marrecas watershed
}

\author{
Carlos G. Tornquist ${ }^{1} \&$ Diego S. da Silva ${ }^{1}$ \\ ${ }^{1}$ Universidade Federal do Rio Grande do Sul/Faculdade de Agronomia/Programa de Pós-Graduação em Ciência do Solo. Porto Alegre, RS, Brasil. \\ E-mail: carlos.tornquist@ufrgs.br - ORCID: 0000-0002-5715-0654; diegosylva@yahoo.com.br (Corresponding author) - ORCID: 0000-0002-2987-7100
}

\begin{abstract}
This study evaluated historic land use and land cover changes in the Arroio Marrecas watershed (Caxias do Sul, Rio Grande do Sul state of Brazil) and simulated future land use scenarios until 2034. Spatial and temporal simulations were conducted with the Conversion of Land Use and its Effects - Small Regional Extent (CLUE-S) model. Three land use scenarios were developed to include public policies and agricultural trends in the study region for 20 years (2015-2034). Geospatial analysis of different land uses showed that areas that were originally covered grasslands and forests decreased, which can be attributed to the expansion of intensive agricultural uses, such as fruit farming/forestry and urbanization. The reallocation dynamics of land use with CLUE-S was primarily driven by the soil class (especially Typic and Humic Dystrudepts and Lithic Undorthents), with limited effects of altitude and slope. Analysis of the land use maps of the Arroio Marrecas watershed until 2015 identified major human-induced changes that were driven by expanding agricultural production and urbanization. The allocation of land use derived from the proposed future scenarios with CLUE-S showed that in this regional context, Humic Dystrudepts and Rhodic Kanhapludults were the key drivers of the allocation of agricultural expansion. Conversely, natural resource conservation was indicated to most likely occur in Typic Dystrudepts. The main limitation of this approach is the recognition of driving factors that have a high correlation with each land use as effective predictor variables.
\end{abstract}

Key words: geospatial analysis, environmental modeling, CLUE-S, grasslands

\section{Cenários atuais e futuros de uso e cobertura das terras na bacia do Arroio Marrecas}

RESUMO: Este estudo avaliou as mudanças históricas do uso do solo e da cobertura da terra na bacia hidrográfica de Arroio Marrecas (Caxias do Sul, RS) e simularam futuros cenários de uso do solo até 2034. As simulações espaciais e temporais foram conduzidas com o modelo CLUE-S ("Conversão de Uso da Terra e seus Efeitos-Pequena Extensão Regional”). Três cenários de uso da terra foram desenvolvidos para incluir políticas públicas e tendências agrícolas na região de estudo por 20 anos (2015-2034). A análise geoespacial mostrou que as áreas com pastagens e florestas diminuíram, o que pode ser atribuído à expansão de usos agrícolas intensivos, como fruticultura, silvicultura e urbanização. A dinâmica de realocação do uso da terra com o modelo CLUE-S foi afetada principalmente pelas classes de solos (especialmente Cambissolo Háplico e Húmico e Neossolo Litólico), com efeito reduzido da altitude e declividade. A análise dos mapas de uso da terra da bacia hidrográfica Arroio Marrecas até 2015 demonstrou mudanças induzidas pelo homem, impulsionadas pela expansão da produção agrícola, além da urbanização. A alocação de uso de terras derivada dos cenários futuros propostos com CLUE-S mostrou que neste contexto regional, Cambissolos e Nitossolos seriam os principais impulsionadores da alocação de expansão agrícola. Por outro lado, as políticas de conservação se mostraram com mais intensidade nos Cambissolos Háplicos. A principal limitação dessa abordagem é o reconhecimento de fatores determinantes que apresentam alta correlação com cada uso da terra como variáveis preditoras efetivas.

Palavras-chave: análise geoespacial, modelagem ambiental, CLUE-S, pastagem

Ref. 192448 - Received 06 Mar, 2018 • Accepted 30 Nov, 2018 • Published 30 Jan, 2019 


\section{INTRODUCTION}

The Arroio Marrecas watershed is primarily dominated by agricultural land uses and includes drinking water sources that are crucial for the growing population of the municipality of Caxias do Sul, Rio Grande do Sul State (which had more than 500,000 inhabitants in 2017).

It has been widely recognized that agricultural expansion has had environmental impacts, such as ecosystem fragmentation, loss of biodiversity and soil, water pollution and disruption of biogeochemical cycles across the world (Rockström et al., 2009) and in Brazil (Dias et al., 2016). Land use and land cover (LULC) assessments usually include spatial and temporal dimensions that allow comparisons of different sites and times to be made in spatial modeling applications (Galharte et al., 2014). These spatial assessments can be enhanced by the inclusion of future LULC scenarios (Shearer, 2005). Numerous studies have reported applications for the development of future scenarios (Verburg et al., 2006). The CLUE-S (Conversion of Land Use and Its Effects - Small Regional Extent) model was developed at the University of Wageningen (Netherlands) to perform spatially explicit simulations of LULC changes from empirical analyses of the suitability and allocation trends of LULC identified in areas of interest. CLUE-S is integrated in a modelling framework (a MS
Windows application) that requires a geoprocessing software for visualization of the output.

The application of CLUE-S initially consists of statistical analysis (logistic regressions) to establish the most important determining factors (drivers) of the LULC change that control the occurrence and location of each LULC class. The conceptual and applied details of CLUE-S are presented and discussed extensively in the literature (Veldkamp \& Fresco, 1996; Verburg et al., 1999, 2002, 2006, 2008, 2010; Verburg \& Veldkamp, 2004; Overmars et al., 2007; Wassenaar et al., 2007; Verburg \& Overmars, 2009), and tutorials are available from the developers (Verburg, 2010). The aims of this study were: a) to create a geospatial database that contains biophysical and LULC information of the Arroio Marrecas watershed, updated with field verification; b) to simulate the allocation of LULC classes in future land use scenarios (until 2034) using CLUE-S.

\section{Material ANd Methods}

The study area comprised the Arroio Marrecas watershed (5,649 ha) in Caxias do Sul municipality (Figure 1).

According to Alvares et al. (2014), the climate in the region is subtropical (Köppen $\mathrm{Cfb}$ ), with mean low temperature of $9{ }^{\circ} \mathrm{C}$ and mean high temperature of $25^{\circ} \mathrm{C}$ and mean annual precipitation of $1690 \mathrm{~mm}$. The geology includes basaltic rocks of
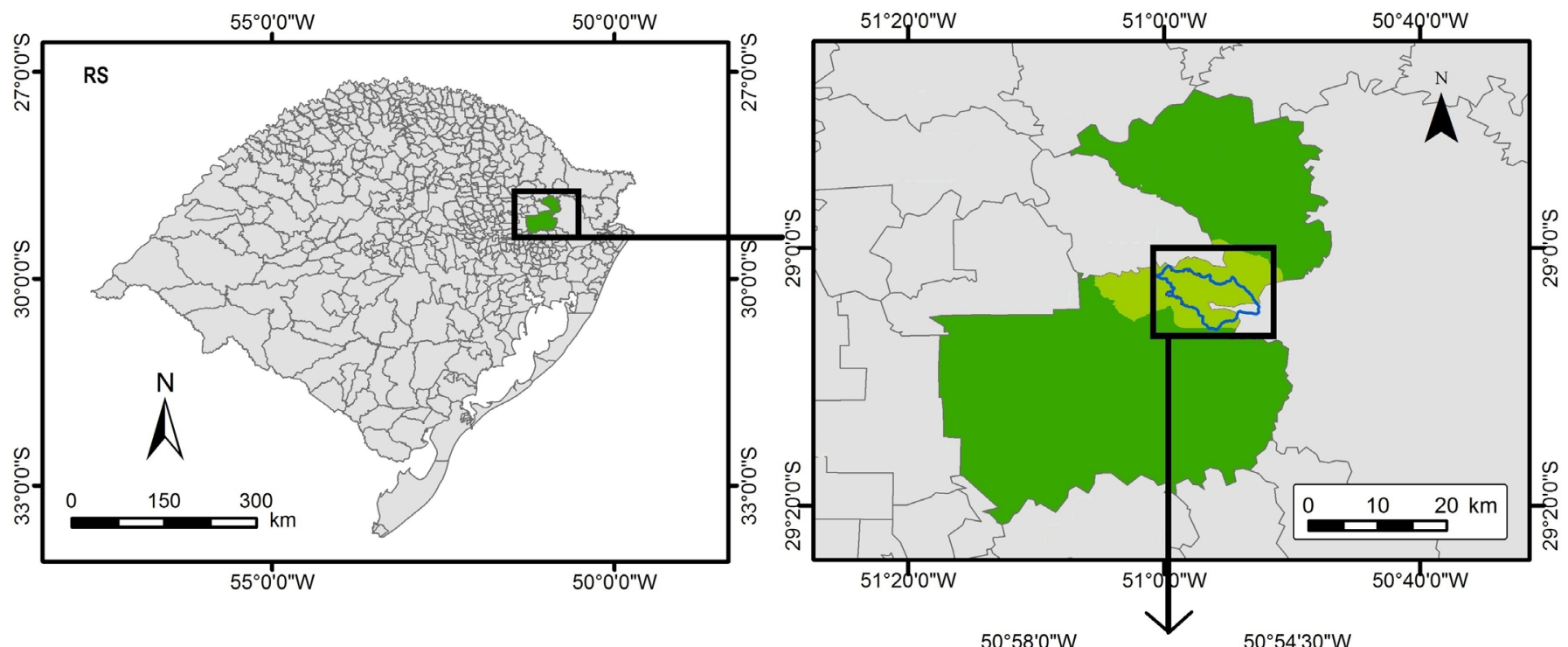

$\underline{\text { Legend }}$

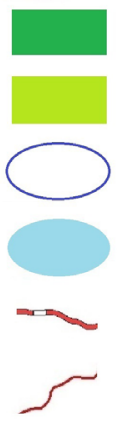

Caxias do Sul

Vila Seca district

Marrecas Watershed boundary

Marrecas reservoir

highway (paved)

unpaved roads

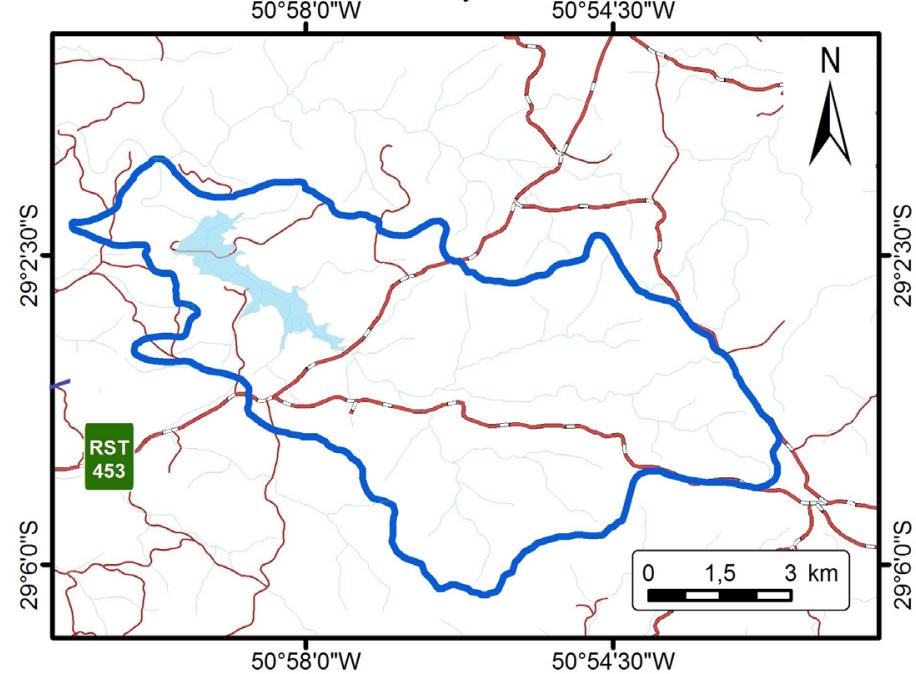

Figure 1. Location of the study region: Arroio Marrecas watershed, Caxias do Sul, Rio Grande do Sul state in Southern Brazil 
the Serra Geral Formation; the original vegetation in the region is a type of Brazilian Atlantic forest (Mixed Ombrophylous Forest) interspersed with grasslands that constitute the Campos de Cima da Serra region in RS (IBGE, 1986). The main soil orders in the region are Humic and Typic Dystrudepts, Lithic Udorthents and Rhodic Kanhapludults (Flores et al., 2012). A notable change in Arroio Marrecas watershed occurred in 2010-2013, when a dam was built near the confluence with the São Marcos River and 215 ha of the riparian zone flooded - mostly bottomlands adjacent to the Arroio Marrecas stream channel. The goal of this infrastructure (with a maximum water storage $=33 \times 10^{6} \mathrm{~m}^{3}$ ) was to supply additional drinking water to the growing population of Caxias do Sul.

Assessment of LULC changes was performed with geoprocessing tools in the ArcGIS environment. An existing vegetation map contracted by the Caxias do Sul Municipal Water Service (SAMAE) in 2010 was used as a reference map. Two additional maps were produced from: a) aerial photographs of the 1965-1966 photogrammetry campaign; b) high resolution satellite imagery (QuickBird and GeoEye satellites) acquired between 2013 and 2014, which were available as ArcGIS basemap (ESRI Geospatial Data Collection) as a georeferenced and orthorectified mosaic of fused multispectral and panchromatic bands. Maps of the LULC were produced by visual interpretation and digitization of vegetation features and anthropic activities on the computer screen using this basemap at a scale of 1:5,000. Ten land use classes were used to identify natural and anthropogenic features in this landscape: grasslands, woodlands, cropland (annual crops), urban zones, silviculture, fruit farming, waters (reservoir of the Arroio Marrecas Dam) and other uses (including small areas with rural buildings and dwellings, areas with exposed soil surface and rocky outcrops). The LULC classification of this last map was verified and corrected when necessary after a field campaign following the complete road network in the watershed $(73 \mathrm{~km})$ in October 2015.

Implementation of the CLUE-S model used explanatory variables that influenced the LULC dynamics that were established with the support of local experts from the Caxias do Sul municipality technical staff. The geomorphological and anthropic attributes that were most likely to correlate to the land use and coverage in the study region were: a) current land use and land cover: the 2015 map obtained as described previously, simplified into six classes: annual crops, forest, fields, forestry/fruit farming, urban area and other uses; b) pedology (Flores et al., 2012); c) hypsometry: digital elevation model of the SRTM (Shuttle Radar Topography Mission) with a spatial resolution of $90 \mathrm{~m}$; d) slope: obtained from the digital elevation model with the ArcGIS Slope function; e) distance from the drainage network: calculated in ArcGIS from the vector hydrographic network; f) distance to roads: calculated in ArcGIS from the vector road network; and g) distance to urban areas: calculated in ArcGIS from the polygons defining urban areas from the map cited above in (a). These map distances were obtained with the Euclidean Distance function, available in the ArcGIS Spatial Analyzer extension. These ArcGIS maps (Figure 2) were created in matrix format (GRID raster format).
Additional data preparation for the CLUE-S application required logistic regression analyses to establish the relationships between the land uses and explanatory variables identified above. The land uses were simplified to include only the main classes observed: cropland (annuals including soybeans, wheat, horticultural crops), woodland, grassland, forestry/fruit farming, and urban zones. Data from the geospatial database were prepared for logistic regression analysis conducted in SAS (Statistical Analysis System). In summary, the ArcGIS raster layers were converted into text files using the CLUE-S tool (File Converter) so that the statistical software could use these files directly to perform the regression analysis, considering each of the explanatory variables chosen (Table 1).

The LULC map for the year 2015 was defined as the baseline to apply the future scenarios of LULC in the CLUE-S simulations. Three alternative scenarios of change were established based on local expert information, who communicated public policies and general agricultural market trends that could influence the region production matrix during the next 20 years (2015-2034): a) scenario 1 pessimistic: $5 \%$ annual increase in cropped areas, annual 5\% decrease in woodlands, $2.5 \%$ annual increase of areas occupied by fruit farming/silviculture and $1 \%$ growth per year of urban zones. The observed LULC change followed the growth trend of cropland in the region over the last 20 years, which comprised conversion of grasslands, which are mainly used for extensive cattle ranching, to cropland, fruit farming, forestry, and urbanization or urban nucleation processes in rural areas. In addition, the woodland suppression restriction introduced by the Brazilian Forest Code (Brasil, 2012) was not considered in this study because it is widely recognized that this Code is not systematically enforced in the region. In fact, tree removal on woodland edges to clear land for annual crops and pastures was observed during field trips in 2015; b) scenario 2 - productivist: an annual cropland increase of $7.5 \%$ and urban zone increase of $1 \%$ per year. This scenario is consistent with the historical and temporal changes that are occurring in the Rio Grande do Sul highlands (Serra Gaúcha), which are derived from the high yields of annual crops, high return from vegetable and fruit production and favorable market structure for these crops in the region. Livestock production in native pastures has been consistently less profitable (Dias et al., 2016; Hermann et al., 2016). This scenario did not allow LULC changes such as riparian vegetation suppression, consistent with legislation (Brasil, 2012); c) scenario 3 - conservationist: this scenario was proposed to advance a context of public policies that are focused on the conservation of water-producing areas in the Caxias do Sul region. This proposition is likely to occur if the initiatives that are already in progress in the northern region of the municipality, such as the Clean Water Program (Caxias do Sul, 2018) and conservation set-aside, are expanded. Scenario 3 would entail a gradual substitution of more intensive land uses (such as agriculture), a $2 \%$ yearly decrease of cropland areas and 5 ha year ${ }^{-1}$ decrease of fruit farming and silviculture, and full compliance with environmental legislation. 

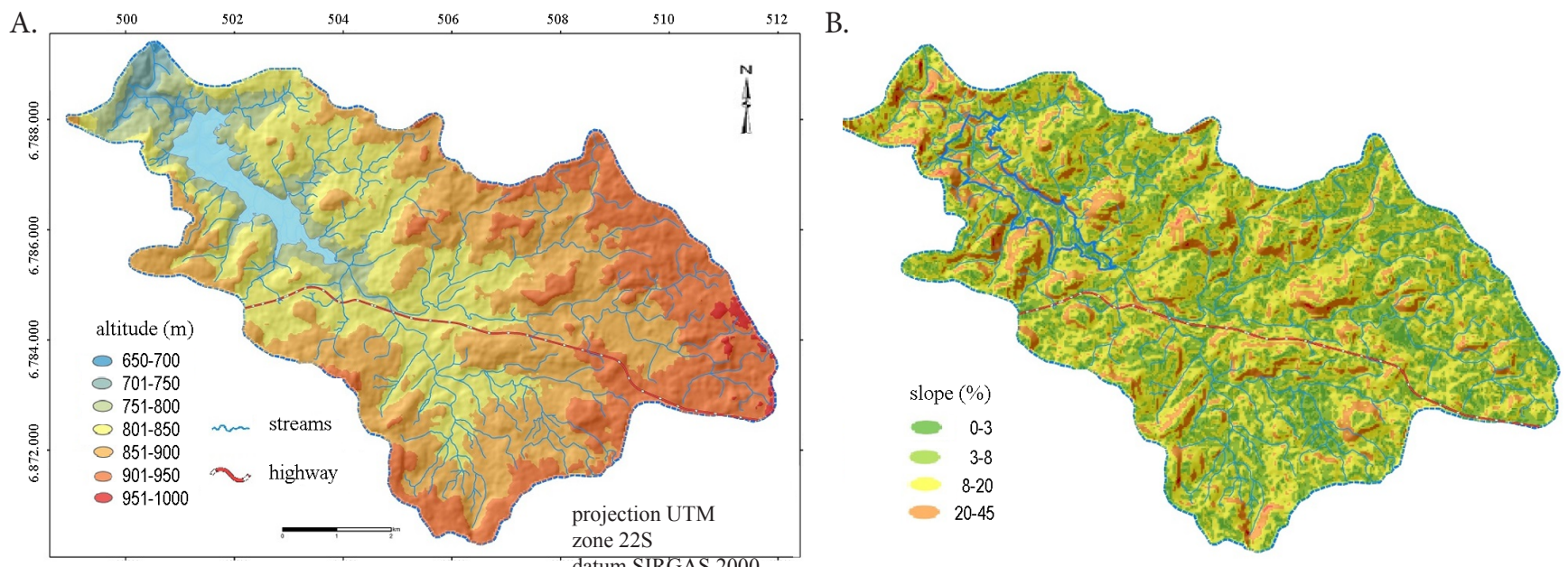

C.
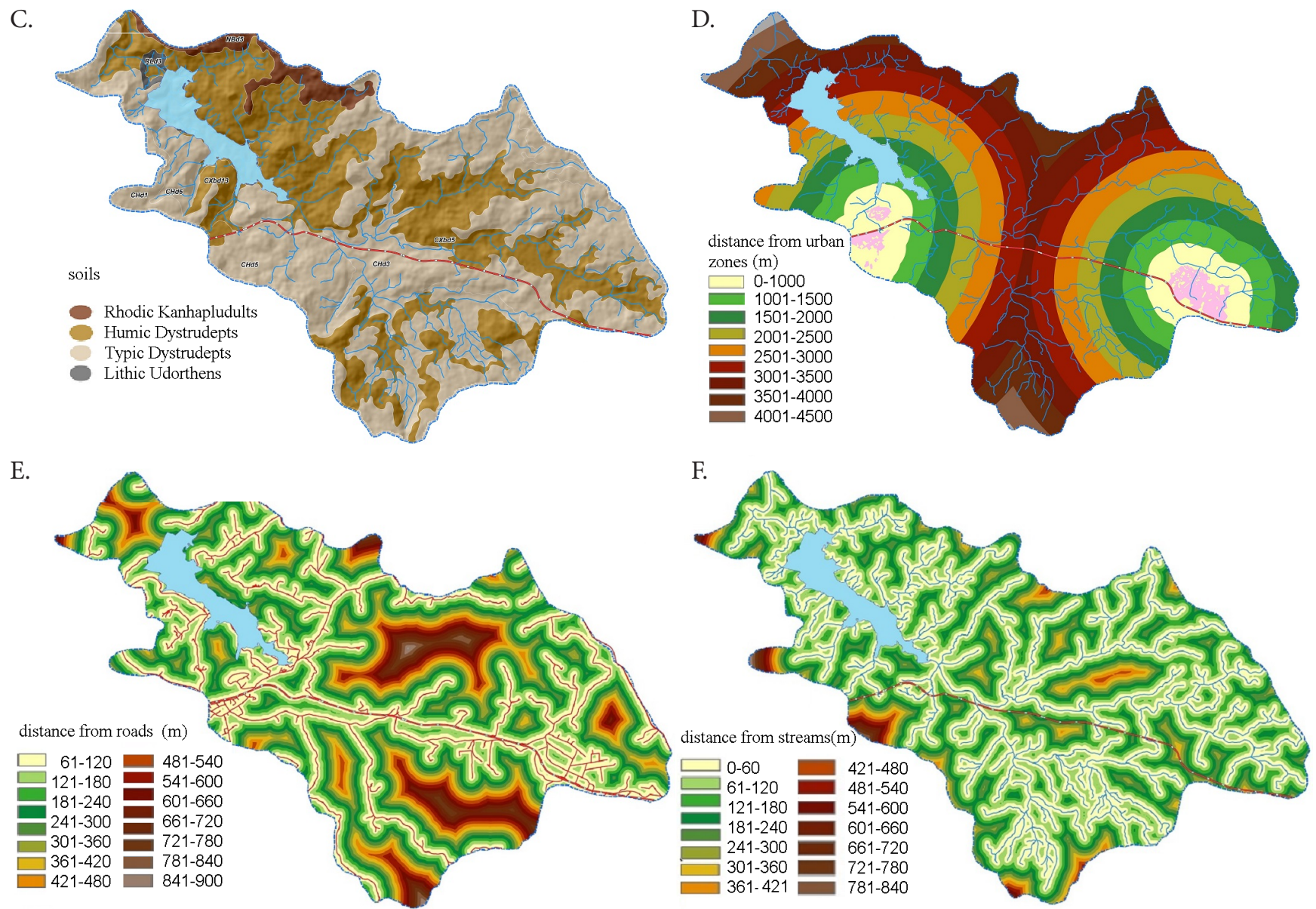

Figure 2. Explanatory factor maps used for CLUE-S simulations: hypsometry (A), slope (B), soils (C), distance from urban areas (D), distance to the road network (E) and distance to the drainage network (F)

Table 1. Results of the logistical regression analysis prior to the CLUE-S application

\begin{tabular}{|c|c|c|c|c|c|}
\hline & \multicolumn{5}{|c|}{ Dependent variables } \\
\hline & Cropland & Woodland & Grasslands & Frut./Silviculture & Urban zone \\
\hline & \multicolumn{5}{|c|}{ Intercept } \\
\hline & -11.6304 & -0.1780 & 1.8263 & -4.1268 & 3.8998 \\
\hline Independent variables & \multicolumn{5}{|c|}{$\beta$ (logistic regression coefficient) } \\
\hline Slope & -0.1001 & 0.0598 & -0.0306 & - & - \\
\hline Distance to road network & -0.0049 & 0.0014 & 0.0003 & -0.0013 & - \\
\hline Distance to drainage network & - & -0.0010 & 0.005 & 0.0015 & - \\
\hline Hypsometry & 0.0099 & - & -0.0026 & - & - \\
\hline Typic Dystrudepts & 0.4161 & - & 0.5844 & - & - \\
\hline Humic Dystrudepts & - & -0.5457 & 1.2529 & -0.7773 & - \\
\hline Rhodic Kanhapludults & 1.3449 & & & - & - \\
\hline Lithic Udorthents & & 0.8529 & - & - & \\
\hline Distance to urban areas & 0.0003 & -0.00006 & - & 0.0006 & -0.2105 \\
\hline
\end{tabular}


Accounting for the land use restrictions imposed by the Brazilian Forestry Code (Brasil, 2012) is required to discard some LULC conversions, such as clear-cutting woodland in riparian zones to make way for agricultural use. Areas with legal restrictions are explicitly treated by CLUE-S with exclusion maps. These maps were prepared in ArcGIS by executing basic geoprocessing operations with the basic thematic layers and also accounting for legal requirements of the Brazilian legislation (Tornquist \& Broetto, 2017), such as APP (Areas of Permanent Preservation). Namely, buffers were created next to the Arroio Marrecas reservoir (100 m from the mean water level) and along the drainage network in the Arroio Marrecas watershed ( $30 \mathrm{~m}$ from the banks, as defined by the mean annual flow). The expected LULC changes in each scenario were applied to the current LULC map (base year 2015) to simulate the allocation of land use after 20 years (Table 2).

To determine the areas that would be occupied in each scenario by a LULC class in the year 2034, CLUE-S simulated the most probable LULC allocation in annual steps using forcing factors as represented by raster maps (Figure 2) and the original (baseline) LULC distribution in the year 2015. CLUE-S executed the allocation algorithm, which was executed cell by cell and considered aptitudes and constraints, according to the steps described in detail by Verburg (2010).

Table 2. Land use and land cover - LULC (areas in hectares) under current and future (+20 years) scenarios at the Arroio Marrecas watershed according to CLUE- simulations

\begin{tabular}{lcccc}
\multirow{2}{*}{ LULC } & \multirow{2015}{*}{} & \multicolumn{3}{c}{$\mathbf{2 0 3 4}$} \\
\cline { 3 - 5 } Cropland & 296 & Scenario 1 & Scenario 2 & Scenario 3 \\
Woodland & 1238 & 1143 & 1168 & 201 \\
Grasslands & 3445 & 2899 & 1238 & 1238 \\
Fruit-/silviculture & 274 & 438 & 2531 & 3618 \\
Urban zones & 121 & 147 & 147 & 179 \\
Other uses & 70 & 70 & 70 & 70 \\
Total area & 5443 & 5443 & 5427 & 5427 \\
\hline
\end{tabular}

\section{Results AND Discussion}

First, analysis of the LULC spatiotemporal dynamics of the LULC in the Arroio Marrecas watershed revealed an increase in anthropic activities, especially the more intensive activities, such as annual crops, fruit growing and forestry, based on agro-industrial inputs (Table 3 ).

Table 3. Land use observed in the Arroio Marrecas watershed in the last 50 years

\begin{tabular}{|c|c|c|c|c|c|c|}
\hline \multirow{2}{*}{ Soil use } & \multicolumn{2}{|c|}{1966} & \multicolumn{2}{|c|}{2010} & \multicolumn{2}{|c|}{2015} \\
\hline & ha & $\%$ & ha & $\%$ & ha & $\%$ \\
\hline Grasslands & 4054 & 71.8 & 3769 & 66.7 & 3319 & 58.8 \\
\hline Woodlands & 1458 & 25.8 & 1374 & 24.3 & 1319 & 23.4 \\
\hline Croplands & 17 & 0.3 & 132 & 2.3 & 255 & 4.5 \\
\hline Water body & 5 & $<0.1$ & 44 & 0.8 & 46 & 0.8 \\
\hline Wetlands & 100 & 1.7 & 78 & 1.4 & 73 & 1.3 \\
\hline Fruit orchards & - & - & 105 & 1.9 & 138 & 2.4 \\
\hline Silviculture & - & - & 89 & 1.6 & 145 & 2.6 \\
\hline Urban zones & 3 & - & 23 & 0.4 & 109 & 1.9 \\
\hline Arroio Marrecas reservoir & - & - & - & - & 196 & 3.5 \\
\hline Other uses & 113 & 2.0 & 34 & 0.6 & 49 & 0.9 \\
\hline Total & 5649 & 100 & 5649 & 100 & 5647 & 100 \\
\hline
\end{tabular}

The conversion of woodland decreased from the previous period (1966-2010) from 84 to 55 ha from 2010-2015, which could be explained by the increasing concern regarding deforestation in Brazil (Sparovek et al., 2010) and increasing legislation enforcement while new land use/land cover legislation was under debate (Brasil, 2012). In addition, some of the recent 55 ha woodland removal was due to the construction of the Arroio Marrecas dam and reservoir filling. This one-off action was demanded by the state environmental agency to ensure long-term water quality in the reservoir and cannot be included in a land use/cover change assessment.

In comparison, approximately $18 \%$ of the area designated as grassland in this region was converted to other land uses over the last 50 years; this value is much less than the reported $60 \%$ loss of these ecosystems that occurred in the Campos de Cima da Serra region (Hermann et al., 2016). Triches et al. (2015) suggested that the maintenance of grasslands could generally be attributed to the direct economic benefit that farmers and ranchers obtain from grazing these lands with beef and dairy cattle. In fact, the economic value of the grasslands has been indicated as being crucial for the conservation of these ecosystems (Pillar et al., 2012).

Additionally, the LULC classes of annual crops, fruit farming and silviculture were shown to have increased, but not exceeding $10 \%$ of the watershed area. The expansion of fruit farming (apple, persimmon, pear, peach, plum) and horticulture (especially cabbage, broccoli, and cauliflower) reflects the concurrent advance of these crops throughout the municipality of Caxias do Sul (Bizotto, 2011), which has also been noted elsewhere in the Campos de Cima da Serra, because of the favorable edaphoclimatic conditions and lax enforcement of environmental legislation that restricts grassland conversion.

Second, the logistic regression analyses presented in Table 1 , which were conducted as the initial step of the CLUE-S implementation, showed that the dynamics of the reallocation of the LULC was primarily defined by the soil class (especially Humic and Typic Dystrudepts) and, to a lesser extent, the altitude and slope. The results indicated that, for example, the highest probability of allocation of annual crops occurred in the areas with Rhodic Kanhapludults, while fruit growing/ silviculture was less likely to take place in Humic Dystrudepts.

The implementation of the proposed scenarios (Table 2 ) in CLUE-S, developed from 2015 (the base year to 2034) using the forcing factors with the relationships derived from the regression analysis, showed the prospective LULC allocation after 20 years. The pessimistic perspective (scenario 1) showed a $152 \%$ increase in cropland (annual crops), $60 \%$ increase in areas occupied by fruit farming and forestry and $21.4 \%$ increase in the urban area, while grassland $(-16 \%)$ and forest $(-8 \%)$ decreased (Figure 3A). As revealed in Figure 3B, which shows the map cells that were reclassified by the CLUE-S algorithm, the allocation of annual crop areas primarily occurred in areas under Typic Dystrudepts and Rhodic Kanhapludults, while fruit farming and silviculture were allocated near water courses and were distant from roads. As these factors only had a small importance in the relationships identified in the logistic regression (Table 1), the allocation executed by CLUE-S was mainly due to the greater ease of allocating new land use to 
map cells adjacent to current land use when these cells were not prioritized for allocation to other lands uses. The same condition was noted in the allocation of urban zones, which expanded to cells at the edges of the areas already occupied by this type of land use.

The productivist outlook (scenario 2) projected a $400 \%$ increase of cropland (annual crops) areas and $21.4 \%$ increase of urban zones, resulting from the conversion of grasslands (Figure 3C). The expansion of urban zones was similarly allocated to that in scenario 1, with growth being assigned to cells surrounded by this type of land use in 2015 (Figure $3 \mathrm{D}$ ). The conservationist projection (scenario 3 ) predicted the substitution of more intensive land uses, leading to a decrease of annual crops (-32\%) and fruit farming/silviculture (-35\%), whereas grasslands increased by $5 \%$ (Figure $3 \mathrm{E}$ ). The detailed

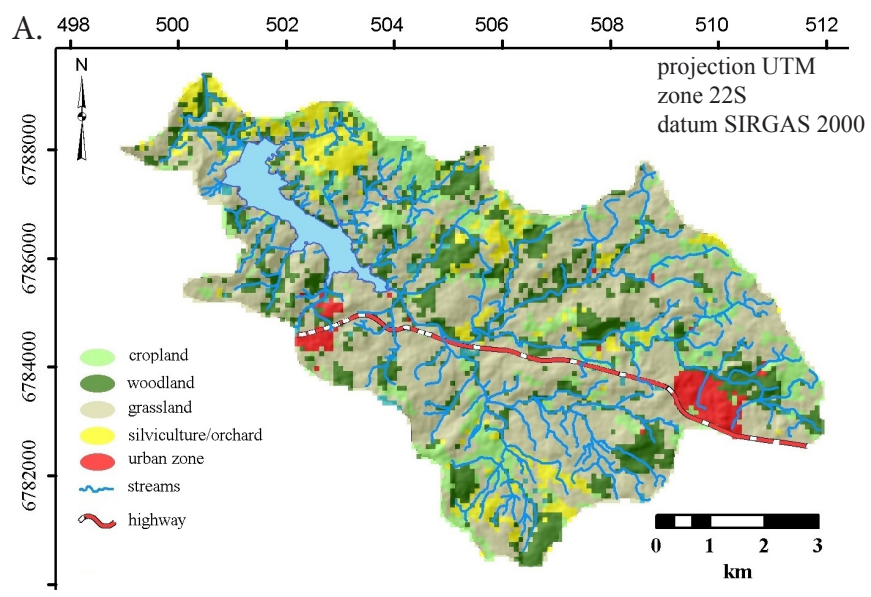

C.

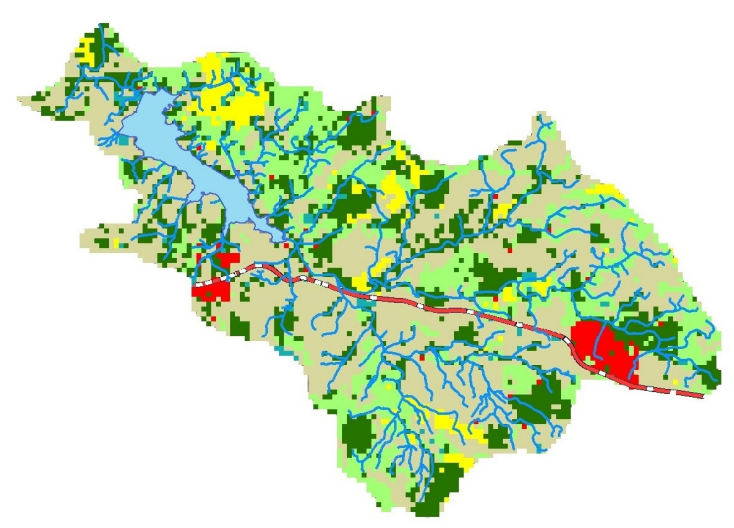

E.

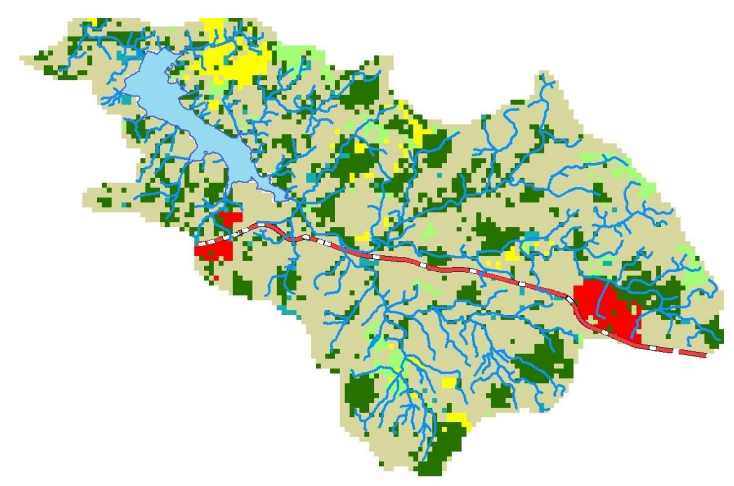

map of the actual changes showed that the allocation of these land uses mainly occurred in the Typic Dystrudepts (Figure $3 \mathrm{~F}$ ), probably because this is the most common soil class in this region and is already used for grazing.

It is emphasized in this study the prominent role of soils to determine the LULC in the context of Southern Brazilian grassland-dominated ecosystems and contemporary anthropic drivers, such as intensive agricultural systems. This result contrasts with the CLUE-S application that assessed future LULC scenarios and model sediment production in watersheds in Southeastern Brazil that was performed by Galharte et al. (2014), who did not establish soils as drivers of LULC change, probably because there was little diversity of soil classes (99\% Oxisols) in the study area. It is highlighted that in the approach adopted in this study, the relationships between LULC and its

B.

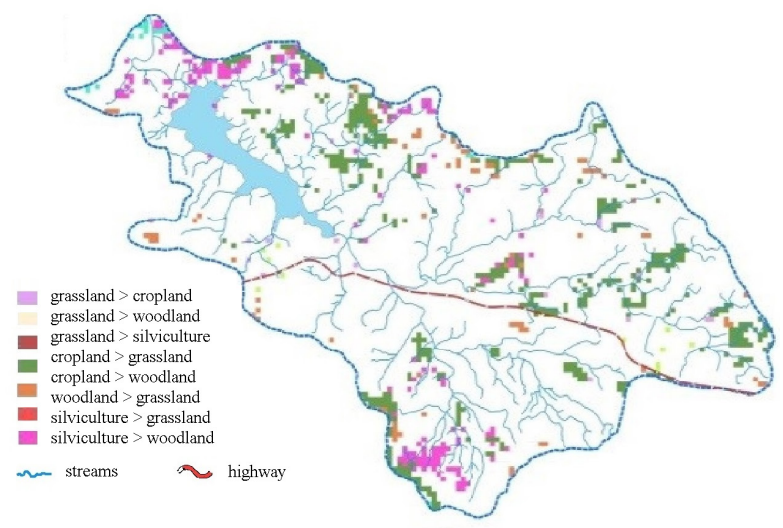

D.

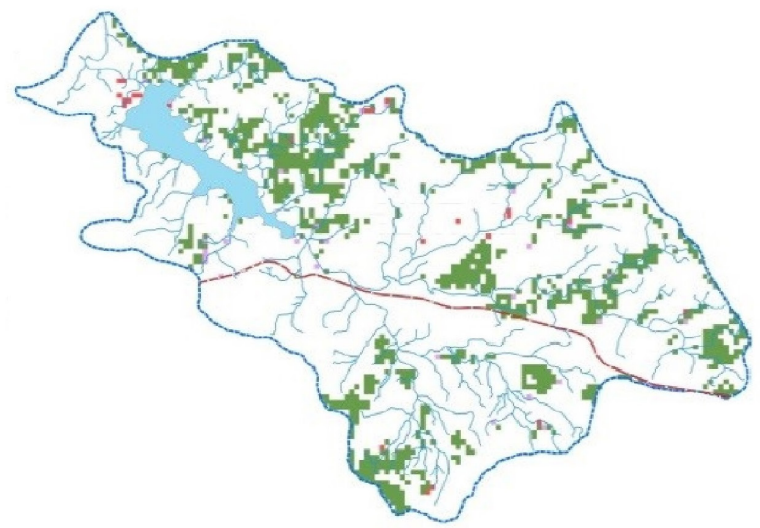

F.

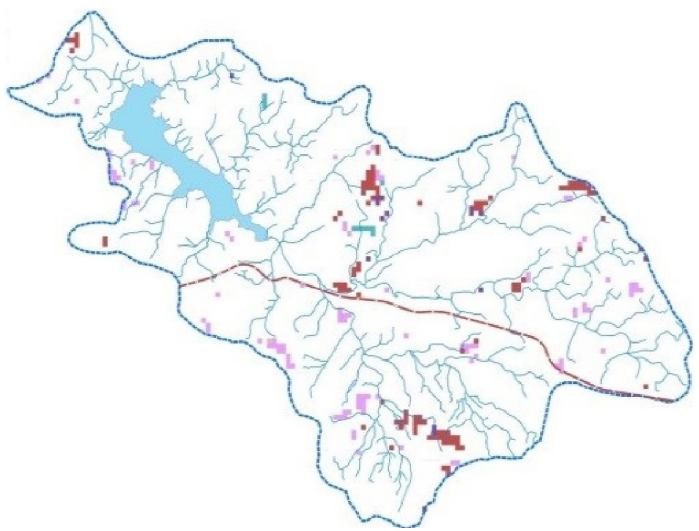

Figure 3. Maps of the land use and land cover (LULC) in 2034 under the different scenarios: pessimist (A); productivist (C); conservationist (E). Map of the land use/cover changes from 2015 to 2034 in the three scenarios as simulated with CLUE-S - grid cells with changes are highlighted $(\mathrm{B}, \mathrm{D}$, and $\mathrm{F})$ 
drivers were also dependent on the work scale, which was also concluded by Aguiar (2006) in a CLUE-S study encompassing the entire Amazon basin. In his study, access to markets (i.e., road network) and ports (inland waterways), as well as existing protected areas (parks and biological reserves), were key explanatory factors. Except for the road network, these drivers were not present in the study area.

The performance of the CLUE-S model was mainly contingent on a robust logistic regression analysis. Some limitations of the CLUE-S model to adequately simulate LULC changes were identified: this type of trend analyses is unable to assess the impacts of transient factors that affect land uses in the study area. For example: a) short-term public policies, such as the public incentives given to large-scale silviculture between 2006-2008 in Rio Grande do Sul; b) conservation initiatives in the Arroio Marrecas watershed, such as purchase of land designated as "water production zones" by the local water authority. The impacts of these events can only be assessed by a long-term study.

\section{Conclusions}

1. Land use and cover change maps of the Arroio Marrecas watershed in Caxias do Sul showed, from 1966 to 2015, a marked trend of expansion of human activities.

2. Simulation of future land use scenarios with the CLUE-S model extending to 2034 based on biogeophysical and anthropic driving factors indicated that in this region, soils are the main driving factor for the spatial allocation of the expected changes related to expanding agricultural production.

3. The CLUE-S model allowed the prediction of spatially explicit, multi-scale, quantitative allocation of potential land use/land cover changes as affected by known drivers.

\section{ACKNOWLEDGMENTS}

The authors thank Soil Science Graduate Program-UFRGS and its supporters, especially from the PROEX-CAPES, for the infrastructure and resources made available to conduct this study. We also acknowledge support from the following entities within the municipal administration in Caxias do Sul: Neiva Rech and Paulo Fachin of the Department of Agriculture and Food Supply for the longstanding partnership in teaching and research and SAMAE (the water and sewage municipal authority of Caxias do Sul).

\section{Literature Cited}

Aguiar, A. P. D. Modeling land use change in the Brazilian Amazon: Exploring intra-regional heterogeneity. São José dos Campos: INPE, 2006. 152p. Tese Doutorado

Alvares, C. A.; Stape, J. A.; Sentelhas, P. C.; Gonçalves, J. L. M.; Sparovek, G. Köppen's climate classification map for Brazil. Meteorologische Zeitschrift, v.22, p.711-728, 2014. https://doi. org/10.1127/0941-2948/2013/0507

Bizotto, B. L. S. Caracterização da cadeia produtiva de pequenas frutas nos campos de cima da serra sob a ótica da produção e comercialização. Caxias do Sul: UCS, 2011. 94p. Dissertação Mestrado
Brasil. Lei No 12.651, de 25 de Maio de 2012. Dispõe sobre a proteção da vegetação nativa e dá outras providências. Disponível em: <http://www.planalto.gov.br/ccivil_03/ato2011-2014/2012/lei/ 112651.htm>. Acesso em: Fev. 2018.

Caxias do Sul. Projeto água limpa. Disponível em: <https://caxias. rs.gov.br/servicos/agricultura/agua-limpa >. Acesso em: Fev. 2018.

Dias, L. C. P.; Pimenta, F. M.; Santos, A. B.; Costa, M. H.; Ladle, R. J. Patterns of land use, extensification, and intensification of Brazilian agriculture. Global Change Biology, v.22, p.2887-2903, 2016. https://doi.org/10.1111/gcb.13314

Flores, C. A.; Pötter, R. O.; Sarmento, E. C.; Weber, E. J.; Hasenack, H. Os solos do Vale dos Vinhedos. Brasília: Embrapa Informação Tecnológica, 2012. 176p.

Galharte, C. A.; Villela, J. M.; Crestana, S. Estimativa da produção de sedimentos em função da mudança de uso e cobertura do solo. Revista Brasileira de Engenharia Agrícola e Ambiental, v.18, p.188193, 2014. https://doi.org/10.1590/S1415-43662014000200010

Hermann, J. M.; Lang, M.; Gonçalves, J.; Hasenack, H. Forest-grassland biodiversity hotspot under siege: Land conversion counteracts nature conservation. Ecosystem Health and Sustainability, v.2, p.1-11, 2016. https://doi.org/10.1002/ehs2.1224

IBGE - Instituto Brasileiro de Geografia e Estatística. Folha SH.22 Porto Alegre e parte das folhas SH.21 Uruguaiana e SI.22 Lagoa Mirim: Geologia, geomorfologia, vegetação, uso potencial da terra. Rio de Janeiro: IBGE, 1986. p.541-632.

Overmars, K. P.; Verburg, P. H.; Veldkamp, A. Comparison of a deductive and an inductive approach to specify land suitability in a spatially explicit land use model. Land Use Policy, v.24, p.584-599, 2007. https://doi.org/10.1016/j.landusepol.2005.09.008

Pillar, V. D.; Tornquist, C. G.; Bayer, C. The southern Brazilian grassland biome: Soil carbon stocks, fluxes of greenhouse gases and some options for mitigation. Brazilian Journal of Biology, v.72, p.673-681, 2012. https://doi.org/10.1590/S151969842012000400006

Rockström, J.; Steffen, W.; Noone, K.; Persson, A. S.; Chapin, F. S.; Lambin, E. F.; Lenton, T. M.; Scheffer, M.; Folke, C.; Schellnhuber, H. J.; Nykvist, B.; Wit, C. A. de; Hughes, T.; Leeuw, S. van der; Rodhe, H.; Sorlin, S.; Snyder, P. K.; Costanza, R.; Svedin, U.; Falkenmark, M.; Karlberg, L.; Corell, R. W.; Fabry, V. J.; Hansen, J.; Walker, B.; Liverman, D.; Richardson, K.; Crutzen, P.; Foley, J. A. A safe operating space for humanity. Nature, v.461, p.472-475, 2009. https://doi.org/10.1038/461472a

Shearer, A. W. Approaching scenario-based studies: Three perceptions about the future and considerations for landscape planning. Environment and Planning B: Planning and Design, v.32, p.67-87, 2005. https://doi.org/10.1068/b3116

Sparovek, G.; Berndes, G.; Barretto, A. O. P.; Klug, I. L. F. Brazilian agriculture and environmental legislation: Status and future challenges. Environmental Science Technology, v.44, p.6046-6053, 2010. https://doi.org/10.1021/es1007824

Tornquist, C. G.; Broetto, T. Protection of the soil resource in the Brazilian environmental legislation. In: Field, D. J.; Morgan, C. L. S.; McBratney, A. B.; (eds.). Global soil security - Progress in soil science. Cham: Springer International Publishing, 2017. Chap.36, p.397-401. https://doi.org/10.1007/978-3-319-43394-3_36

Triches, D. Agropólo da Serra Gaúcha: Uma alternativa de desenvolvimento regional a partir da inovação e difusão tecnológica. Revista Baiana de Tecnologia, v.17, p.47-56, 2015. 
Veldkamp, A.; Fresco, L. O. CLUE-CR: An integrated multi-scale model to simulate land use change scenarios in Costa Rica. Ecological Modelling, v.91, p.231-248, 1996. https://doi. org/10.1016/0304-3800(95)00158-1

Verburg, P. H. The CLUE modelling framework: The conversion of land use and its effects. Amsterdam: University Amsterdam/ Institute for Environmental Studies, 2010. 53p.

Verburg, P. H.; Berkel, D. V.; Doorn, A. V.; Eupen, M. V.; Heiligenberg, H. A. R. M. V. Trajectories of land use change in Europe: A model-based exploration of rural futures. Landscape Ecology, v.25, p.217-232, 2010. https://doi.org/10.1007/s10980-009-9347-7

Verburg, P. H.; Eickhout, B.; Meijl, H. van. A multi-scale, multi-model approach for analyzing the future dynamics of European land use. Annals of Regional Science, v.42, p.57-77, 2008. https://doi. org/10.1007/s00168-007-0136-4

Verburg, P. H.; Koning, G. H. J. de; Kok, K.; Veldkamp, A.; Bouma, J. A spatial explicit allocation procedure for modelling the pattern of land use change based upon actual land use. Ecological Modelling, v.116, p.45-61, 1999. https://doi.org/10.1016/S03043800(98)00156-2
Verburg, P. H.; Overmars, K. P. Combining top-down and bottom-up dynamics in land use modeling: Exploring the future of abandoned farmlands in Europe with the Dyna-CLUE model. Landscape Ecology, v.24, p.1167-1181, 2009. https://doi.org/10.1007/s10980-009-9355-7

Verburg, P. H.; Soepboer, W.; Limpiada, R.; Espaldon, M. V. O.; Sharifa, M. A.; Veldkamp, A. Modeling the spacial dynamics of regional land use: The CLUE-S model. Environmental Management, v.30, p.391-405, 2002. https://doi.org/10.1007/s00267-002-2630-x

Verburg, P. H.; Veldkamp, A. Projecting land use transitions at forest fringes in the Philippines at two spatial scales. Landscape Ecology, v.19, p.77-98, 2004. https://doi.org/10.1023/ B:LAND.0000018370.57457.58

Verburg, P. H.; Veldkamp, A.; Rousevell, M. D. A. Scenario-based studies of future land use in Europe. Agriculture, Ecosystems and Environment v.114, p.1-6, 2006. https://doi.org/10.1016/j.agee.2005.11.023

Wassenaar, T.; Gerber, P.; Rosales, M.; Ibrahim, M.; Verburg, P. H.; Steinfeld, H. Predicting land use changes in the Neotropics: The geography of pasture expansion into forest. Global Environmental Change, v.17, p.86-104, 2007. https://doi.org/10.1016/j. gloenvcha.2006.03.007 